\title{
Cultivar diversification of banana production in Brazil
}

\author{
Gabriel Maluf Napoleão ${ }^{1, *}\left({ }^{*}\right.$, Paulo Ricardo Rodrigues de Jesus ${ }^{1}\left([)\right.$ and Sarita Leonel ${ }^{1}(0)$ \\ ${ }^{1}$ Universidade Estadual Júlio de Mesquita Filho (UNESP), Faculdade de Ciências Agronômicas (FCA), Campus Botucatu, Av. \\ Universitária, $\mathrm{n}^{\circ}$ 3780, Altos do Paraíso, CEP: 18610-034, Botucatu, SP, Brazil. *Corresponding author, E-mail: \\ gabrielmaluf275@gmail.com
}

\begin{abstract}
Bananas fruits are widely consumed in the world. In Brazil, the role of agriculture activities in the economy and society is huge, especially for banana farmers. The most popular variety of bananas in Brazil are Prata, Grand Naine, Williams and Nanicão; however, all of them have at least one undesirable trait such as height, yield, vegetative cycle, pests and diseases tolerances, drought or cold resistance and fruit quality. This literature review aims to evaluate agronomic performance and fruit quality of new genotypes of the Prata and Cavendish subgroups, and to make further recommendations on high quality genotypes to Brazilian banana producers. Therefore, a literature review of previously acquired data was conducted and the outcomes indicated genotypes' adaptability to specific region that assessed vegetative and productive attributes of new cultivars, in comparison to most commercially exploited ones, which have already shown high vulnerability to pests and diseases. These outcomes will then facilitate banana producers the opportunity to select the most stable and adaptable genotypes according to environmental conditions.
\end{abstract}

Keywords: Cultivars, agronomic performance, plant breeding, taste banana, organoleptic characteristics, Musa sp.

\section{INTRODUCTION}

The production of banana plays a key role in international agribusiness, as banana is known to be among the most consumed and appreciated fruits in the world (Lima, Silva, \& Ferreira, 2012; Destro, Souza-Junior, Lima, Miranda, \& Ferreira, 2020). Moreover, there are many ways to enjoy this versatile fruit, in addition to their organoleptic characteristics and the ease process of acquisition and consumption. Banana crops (Musa spp.) are grown in tropical and subtropical regions across the world and has social-economic benefits due to the ongoing production cycle and quick return, that is, a fast source of income of smallholder farmers (Deltour et al., 2017).

The world banana production in 2018 reached 115.74 million tons harvest in a planted area of 5.73 million hectares. The main world producers were India (30.80 million tons), China (11.22 million tons), Indonesia (7.26 million tons) and Brazil (6.75 million tons) (Food and Agriculture Organization of the United Nations [FAO], 2020). In Brazil, São Paulo (state) was the largest banana producer in 2019, accounting 1.12 million tons, followed by Bahia (1,040,000 tons), Minas Gerais ( 820,113 tons), Santa Catarina (719,571 tons) and Pernambuco (437,262 tons) (Instituto Brasileiro de Geografia e Estatística [IBGE], 2020).

Most of the small, medium, and large Brazilian producers have grown cultivars of the Cavendish subgroup ('Prata', 'Nanica', 'Nanicão' and 'Grand Naine') and Maçã subgroup. However, these cultivars are highly susceptible to crop diseases such as yellow sigatoka (Mycosphaerella musicola, Leach), black sigatoka (Mycosphaerella fijiensis, Morelet) and Panama disease (Fusarium oxisporumf. F. sp. cubense). Also, the damages caused by these diseases can be a total loss for the crop (100\%), that is, a substantial impact in the production (Silva, Amorim, Santos-Serejo, Ferreira, \& Rodriguez, 2013b; Empresa Brasileira de Pesquisa Agropecuária [EMBRAPA], 2012). In a search for a phytosanitary solution with regards to traditional crop matters over the years, new banana cultivars have been developed through genetic improvement to make feasible the commercial use of high-quality hybrids (Silva, Alves, Lima, \& Silveira, 2002).

In Brazil, there are many banana cultivars available for commercial use, but consumers and producers expect significant fruit traits that narrow down the options. To make ends meet, there is a need of studies on cultivars that are most suitable for specific environment to then evaluate fruit quality and agronomic performance (Aular \& Natale, 2013). Given all the above, this study aims to gather information through a literature review regarding varietal diversification of cultivars belonging to Prata and Cavendish subgroups; 


\section{THE CULTIVAR DIVERSIFICATION OF THE PRATA SUBGROUP}

'Prata Anã' is the most commercially exploited cultivar in Brazil (Azevedo, Donato, Arantes, Maia, \& Silva, 2010). This cultivar belongs to Prata subgroup and, therefore, the genetic origin is resulted from the mutation of Branca cultivar (Silva, Shepherd, Alves, \& Dantas, 1999). Furthermore, Prata Anã is cold tolerant, but susceptible to yellow and black sigatoka, besides having an intermediate susceptibility to Panama disease (Borges \& Souza, 2004).

Developing new genotypes is an important strategy to alleviate or even solve the problems that affect banana plants directly or indirectly across the world, since these new genotypes can present desirable traits such as pests and diseases resistance, small size, high yield, great quality fruits after post-harvest and fruits that are highly appreciated by consumers (Silva et al., 2003). Many institutions have therefore conducted genetic improvement programmes such as Embrapa Cassava and Tropical Fruit (Brazil) and Fundación Hondureña de Investigacón Agrícola (FHIA, Honduras), both of them assess banana breeding programmes to develop superior performance of tetraploid hybrids from crosses between typical triploids and diploids (Table 1) (Silva et al., 2003; Lichtemberg \& Lichtemberg, 2011).

In 2005, Embrapa Western Amazon in Manaus selected and recommended the BRS Vitória cultivar to producers in the state of Amazonas (Embrapa, 2020a). This tetraploid hybrid (AAAB) is resulted from the cross between triploid Pacovan (AAB) and M-53 diploid (AA). This cultivar is resistant to black and yellow sigatoka, Panama disease and anthracnose during post-harvest; consequently, this cultivar enables fruits with longer shelf life. Moreover, it presents great yield that can go up to $44 \mathrm{t} \mathrm{ha}^{-1}$ at satisfactory conditions. The plants are tall and have good tillering, like the cultivars of Prata subgroup. BRS Vitória can be grown at greater planting densities (i.e. 1.538 plants ha $^{-1}$ ). Furthermore, ripe fruits have an intense yellow peel, cream coloured pulp, less pronounced acidity and are sweeter than 'Prata Comum' fruits (Pereira, Gasparoto, \& Pereira, 2005a).

In 2010, the cultivar BRS Japira was launched by Embrapa Cassava and Tropical Fruit culture, in the state of Bahia (Embrapa, 2020b). This hybrid is resulted from the cross between Pacovan triploid (AAB) and M-53 diploid (AA). 'BRS Japira' is resistant to important pests and diseases related to banana farming, such as Panama disease, anthracnose, black and yellow sigatoka. They are tall and have good tillering, which similar traits are found in other cultivars of the Prata subgroup. The ripe fruits have a cream coloured pulp, intense yellow peel, and less acidity than 'Prata Comum' fruits (Pereira, Gasparoto, \& Pereira, 2005b).

The BRS Platina cultivar was launched by Embrapa Cassava and Tropical Fruit Culture (Bahia, Brazil) in 2012, this tetraploid hybrid (AAAB) is a result from the cross between Prata Anã (AAB) with M-53 diploid. The plants are resistant to Panama disease and yellow sigatoka. They are medium sized, have an average yield $\left(20 \mathrm{t} \mathrm{ha}^{-1}\right.$ ) and cycle duration of 375 days (Amorim \& Santos-Serejo, 2011; Embrapa 2012). This cultivar produces large sized fruits with light green colour, great flavour, improved acidity traits, but less sweet than 'Prata Anã' fruits (Oliveira, Donato, Mizobutsi, Silva, \& Mizobutsi, 2013; Donato, Arantes, Silva, \& Cordeiro, 2009).

There are some other examples of hybrids belonging to Prata subgroup that have been studied as an alternative to most traditional cultivars, such as 'Prata Zulu', which is originally from Africa. This cultivar also presents resistance against black and yellow sigatoka, but susceptible to other pests and diseases that could affect the whole banana orchard. The plants of 'Prata Zulu' are tall and have good tillering, but a long cycle (401 days in the Amazon region). The cluster weighs from 20 to $25 \mathrm{~kg}$ with an average of 10 bunches each, resulting in an expected yield of $33 \mathrm{t} \mathrm{ha}^{-1}$ in the first cycle and $49.9 \mathrm{t} \mathrm{ha}^{-1}$ in the second one. The fruits have a bittersweet flavour with a sticky and grey coloured pulp (Fancelli, 2003).

FHIA 18 and Prata Grauda cultivars are both tetraploids (AAAB group) which were developed by The Honduras Foundation for Agricultural Research (FHIA) (Fancelli, 2003; Silva, Santos-Serejo, \& Cordeiro, 2004). Moreover, both are potential alternatives to the traditional cultivars of Prata subgroup. The 'FHIA 18' hybrid is a result of the cross between Prata Anã (AAB) and SH-3142 diploid and, therefore, has similar traits as cultivars of the Prata subgroup (Cruz-Junior et al., 2007; Godoy et al., 2016). With regards to 'FHIA 18', the plant height can reach up to $2.7-3.65 \mathrm{~m}$ and the pseudo-stem perimeter ranges between 84.9 to $96 \mathrm{~cm}$. This plant contains from 11 to 14 leaves during flowering, the vegetative cycle varies from 282 to 435 days and the cluster weighs between 20.7 and $32 \mathrm{~kg}$ (Nomura et al., 2013; Donato et al., 2009). 'FHIA 18' has good tillering; yield can exceed 20 tons per hectare and fruits with length up to $15 \mathrm{~cm}$ (Fancelli, 2003). This cultivar is resistant to black sigatoka and an intermediate susceptibility to yellow sigatoka; but susceptible 
to bacterial diseases that commonly affect banana orchards (Smith, Langdon, Pegg, \& Daniells, 2014).

Prata Grauda cultivar was developed by the cross between 'Prata Anã' and diploid SH-3393. This cultivar produces a great amount of large sized fruits with more astringent flavour than 'Prata Anã' fruits. The plants are medium sized with a vegetative cycle of 360 days; the cluster weighs about $25 \mathrm{~kg}$ and the yield of $50 \mathrm{t}$ $\mathrm{ha}^{-1}$. Being resistant to Panama disease, an intermediate susceptibility to yellow sigatoka, but susceptible to moko and nematodes (Silva et al., 2004).

FHIA 01 is another cultivar developed by The Honduras Foundation for Agricultural Research (FHIA). This hybrid is a result from the cross between 'Prata Anã' and SH-3142 diploid (AA) (Dantas, 1999). The plant is tall and have good tillering; the vegetative cycle lasts about 353 days. The cluster weighs around $24 \mathrm{~kg}$ with 10 bunches each. FHIA 01 is a potential alternative to 'Prata Comum' due to their resistance against yellow and black sigatoka (Fancelli, 2003), among other positive traits such as tolerance to low temperatures, drought periods and reduced soil fertility. Moreover, bunches present good size and post-harvest duration with flavoured and textured fruits (Dantas, 1999).

Table 1: Main characteristics of traditional cultivars and tetraploid hybrids belonging to Prata subgroup.

\begin{tabular}{|c|c|c|}
\hline CULTIVAR & CHARACTERISTICS & REFERENCES \\
\hline Prata Anã & $\begin{array}{l}\text { Genotype: } A A B ; \\
\text { Susceptible to: black and yellow sigatoka and Panama } \\
\text { disease; } \\
\text { Size: small/ medium; } \\
\text { Vegetative cycle: } 407 \text { days; } \\
\text { Cluster weight: } 14 \text { a } 16 \mathrm{~kg} ; \\
\text { Number of bunches: } 8 \text {; } \\
\text { Yield: } 24 \text { t ha }{ }^{-1} \text {; } \\
\text { Fruit length: } 10 \text { a } 13 \mathrm{~cm} \text {; } \\
\text { Fruit diameter: } 3.5 \text { a } 4 \mathrm{~cm} .\end{array}$ & $\begin{array}{l}\text { (Silva \& Rodrigues, } \\
\text { 2013a; Roque et al., } \\
\text { 2014; Silva et al., 1999; } \\
\text { Silva et al., 2004) }\end{array}$ \\
\hline Pacovan & $\begin{array}{l}\text { Genotype: } A A B ; \\
\text { Susceptible to: black and yellow sigatoka and Panama } \\
\text { disease; } \\
\text { Size: tall; } \\
\text { Vegetative cycle: } 350 \text { days; } \\
\text { Cluster weight: } 16 \mathrm{~kg} \text {; } \\
\text { Number of bunches: } 7 \text {; } \\
\text { Yield: } 40 \mathrm{t} \mathrm{ha}^{-1} \text {; } \\
\text { Fruit length: } 18.8 \mathrm{~cm} \text {; } \\
\text { Fruit diameter: } 3.4 \mathrm{~cm} \text {. }\end{array}$ & $\begin{array}{l}\text { (Silva et al., 2013; } \\
\text { Roque et al., 2014; } \\
\text { Embrapa 2012, Donato } \\
\text { et al., 2009) }\end{array}$ \\
\hline Prata Zulu & $\begin{array}{l}\text { Genotype: AAB; } \\
\text { Susceptible to: Panama disease; } \\
\text { Resistant to: black and yellow sigatoka; } \\
\text { Size: tall; } \\
\text { Vegetative cycle: } 401 \text { days; } \\
\text { Cluster weight: } 20 \text { a } 25 \mathrm{~kg} ; \\
\text { Number of bunches: more than } 10 \text { per cluster; } \\
\text { Yield: } 33 \text { a } 49 \mathrm{t} \mathrm{ha}^{-1} \text {; } \\
\text { Fruit length: } 15 \mathrm{~cm} ; \\
\text { Fruit diameter: } 3.4 \mathrm{~cm} \text {. }\end{array}$ & $\begin{array}{l}\text { (Fancelli, 2003; Ramos, } \\
\text { 2008) }\end{array}$ \\
\hline FHIA 01 & $\begin{array}{l}\text { Genotype: AAAB; } \\
\text { Susceptible to: Panama disease; } \\
\text { Resistant to: black and yellow sigatoka; } \\
\text { Size: tall; } \\
\text { Vegetative cycle: } 353 \text { days; } \\
\text { Cluster weight: } 24 \mathrm{~kg} \text {; } \\
\text { Number of bunches: } 10 ; \\
\text { Yield: } 43.1 \mathrm{t} \mathrm{ha}{ }^{-1} ; \\
\text { Fruit length: } 22.4 \mathrm{~cm} \text {; } \\
\text { Fruit diameter: } 3.6 \mathrm{~cm} \text {. }\end{array}$ & $\begin{array}{l}\text { (Dantas, 1999; Fancelli, } \\
\text { 2003; Ramos, 2008) }\end{array}$ \\
\hline
\end{tabular}


Genotype: AAAB;

Susceptible to: yellow sigatoka and Panama disease;

Resistant to: black sigatoka;

Size: small/ medium;

FHIA 18

Vegetative cycle: 383 days;

(Fancelli, 2003; Silva et

Cluster weight: $40 \mathrm{~kg}$;

al., 2004)

Number of bunches: more than 10 per cluster;

Yield: $20 \mathrm{t} \mathrm{ha}^{-1}$;

Fruit length: $15 \mathrm{~cm}$;

Fruit diameter: $3.18 \mathrm{~cm}$.

Genotype: AAAB;

Susceptible to: yellow and black sigatoka;

Resistant to: Panama disease;

Size: medium;

Prata Graúda

Vegetative cycle: 360 days;

Cluster weight: $25 \mathrm{~kg}$;

(Silva et al., 2004)

Number of bunches: 9;

Yield: $50 \mathrm{t} \mathrm{ha}^{-1}$;

Fruit length: $22.7 \mathrm{~cm}$;

Fruit diameter: $3.70 \mathrm{~cm}$.

Genotype: AAAB;

Resistant to: yellow and black sigatoka, and Panama

disease;

Size: tall;

(Donato et al., 2009;

Vegetative cycle: 455 days;

Pacovan Ken Cluster weight: $19.67 \mathrm{~kg}$;

Weber, Santos Garruti,

Number of bunches: 8;

Norões, \& Silva, 2017)

Yield: $20 \mathrm{t} \mathrm{ha}^{-1}$;

Fruit length: $21 \mathrm{~cm}$;

Fruit diameter: $3.35 \mathrm{~cm}$.

Genotype: AAAB;

Resistant to: black and yellow sigatoka, and Panama

disease;

Size: tall;

BRS Preciosa

Vegetative cycle: 447 days;

(Donato et al., 2009,

Cluster weight: $19.33 \mathrm{~kg}$;

Embrapa 2020b)

Number of bunches: 7;

Yield: 20 t ha $^{-1}$;

Fruit length: $20.3 \mathrm{~cm}$;

Fruit diameter: $3.46 \mathrm{~cm}$.

Genotype: AAAB;

Resistant to: black and yellow sigatoka, and Panama

disease;

(Embrapa, 2020a,

Size: tall;

BRS Japira

Vegetative cycle: 459 days;

Donato et al., 2009;

Cluster weight: $19.69 \mathrm{~kg}$;

Weber et al., 2017;

Number of bunches: 8;

Yield: 25 to $31 \mathrm{t} \mathrm{ha}^{-1}$;

Nogueira et al., 2018)

Fruit length: $20.5 \mathrm{~cm}$;

Fruit diameter: $3.30 \mathrm{~cm}$. 
Genotype: AAAB;

Resistant to: black and yellow sigatoka, and Panama

disease;

(Amorim \& Santos-

Size: medium;

BRS Platina

Vegetative cycle: 375 days;

Serejo., 2011; Embrapa,

Cluster weight: $17.13 \mathrm{~kg}$;

2012, Weber et al.,

Number of bunches: 7;

Yield: 20 a 40 t ha $^{-1}$;

Fruit length: $21 \mathrm{~cm}$;

Fruit diameter: $3.8 \mathrm{~cm}$.

Genotype: AAAB;

Resistant to: black and yellow sigatoka, and Panama

disease;

Size: tall;

BRS Vitória

Vegetative cycle: 307 days;

(Pereira et al., 2005b,

Cluster weight: $23 \mathrm{~kg}$;

Weber et al., 2017)

Number of bunches: 8;

Yield: $32 \mathrm{t} \mathrm{ha}^{-1}$;

Fruit length: $21.3 \mathrm{~cm}$;

Fruit diameter: $3.4 \mathrm{~cm}$.

\section{AGRONOMIC PERFORMANCE AND FRUIT QUALITY OF CULTIVARS BELONGING TO PRATA SUBGROUP}

Among the best cultural practices in banana production, one must consider the plant height, since is an important trait for planting density tolerance and fruit harvesting, that is, direct factors that influence the cost of the fruits. Besides that, it is an important criterion for selecting the most appropriate cultivar according to specific regions with regards to the incidence of gusty winds (Nogueira, et al., 2018).

In a study that assessed the vegetative development of banana genotypes in the edaphoclimatic conditions of Vale do Ribeira, Nomura et al. (2013), found that the small-sized genotypes (BRS Platina, FHIA 18 and Prata Anã cultivars) presented the average heights between 2.66 to $3.56 \mathrm{~m}$ in the first and second cycle.

Nomura et al. (2013) found the largest pseudo-stem diameters in cultivars of the AAAB group, which is related to 'Prata', as follows: BRS Maravilha, Prata Anã, BRS Platina and BRS Garantida. This characteristic is crucial for genetic improvement of banana, since pseudo-stem diameter is related to vigor and the capacity of the plant to support the cluster weight (Silva et al., 1999), besides having a positive correlation with production traits (Perez, Simão, \& Manica, 1973)

The phenological cycles of banana plants are directly related to the early harvest of their fruits, as it indicates the number of days necessary for bunch emission and formation and, consequently, anticipates the return on invested capital (Santos et al., 2006). In subtropical regions, studies are needed to identify the most stable and adapted cultivars, since banana farming is originally grown in tropical climates. Therefore, an experiment was conducted in the region of São Manuel, state of São Paulo, the authors found the FHIA 18 hybrid presented the longest production cycle (i.e. a late cultivar) with an adequate cultivation potential due to good productive performance under the evaluated conditions (Bolfarini, Javara, Leonel, \& Leonel, 2014).

Among banana cultivars, there is often a great variation due to their intrinsic characteristics. These differences may be regarded to the variation of fruit size and shape or in the number of fruits and hands per bunch. Banana plants of the Cavendish subgroup commonly produce larger bunches than Prata subgroup (Alves, 1999). However, these characteristics also depend on the orchard's edaphoclimatic conditions and cultural practices adopted (Borges \& Souza, 2004).

In a research carried out in the sub-middle region of the São Francisco valley, Silva, Jesus, Anjos, Machado and Ribeiro, (2016), evaluated the production and fruit quality of the banana cultivars 'BRS Maravilha' and 'BRS Preciosa' in the first and second production cycle. Then, 'BRS Maravilha' presented a higher number of bunches per cluster in the second cycle, which is crucial for producers and breeders, since the bunch (banana fruits) is the commercial unit, according to Silva, Pires, Pestana, Alves and Silveira, (2006).

Fruit dimensions and weight are attributes regarded to genetic association and high heritability; these 
factors are relevant for assessing cluster yield of a given cultivar (Tenkouano, Ortiz, \& Baiyeri, 2002). In the Jaguaribe-Apodi plateau (Brazilian north-eastern), a study was carried out to evaluate growth and production of 20 banana genotypes that are resistant to black sigatoka. They were then compared to the most common cultivars grown by farmers, which are susceptible to the disease, Weber et al. (2017) found that 'BRS Tropical' presented lower weight and size than almost all other genotypes. The shape of these resistant genotypes is highly desirable, since are like 'Prata Anã' and, therefore, meeting consumer's preference (Matsuura, Costa, \& Folegatti, 2004).

For commercial production of bananas, planting density highly influences on plants growth and development due to the competition for sunlight among them. The management of plant population density is needed to control the amount of sunlight that is received by the crop. In this way, high planting density impact on the agronomic performance, which can decrease, as there is an increase in the competition for sunlight, besides that, there are also the matters of water loss through transpiration and the incidence of pests and diseases (Cayón, Valencia, Morales, \& Domínguez, 2004). In Los Angeles, Los Rios Province in Ecuador, Cartazar; Wolf and Gonzalez (2015) determined the optimal planting density for 'Barraganete' (AAB) genotype during the first production cycle. The authors concluded the best planting density is around 2800 and 3000 plants. ha ${ }^{-1}$; however, fruits destined for the foreign market should be around 2500 plants. ha-1.

In a study carried out in the southwest of Bahia, Magalhães et al. (2020) analysed the production and water use efficiency (WUE) of 'Prata Anã' under irrigation depths and planting densities. According to them, the planting density that results in 3333 plants. ha $^{-1}$ reduces the yield with regards to the fruit's productive traits. However, it increases in yield and keeps the fruits commercial classification, regardless of the irrigation depth.

Furthermore, banana plants have a relatively high nutrient demand, because of not only the high accumulation and export of nutrients, but also is commonly grown in soils with nutrient deficiency, mainly nitrogen, phosphorus, and potassium (Silva \& Borges, 2008). The fertilizer recommendations for banana plants in Brazil are not specified for different subgroups and cultivars (Nomura et al., 2013). However, these recommendations should also consider both climate and soil conditions of each region, in addition to the nutritional needs of each cultivar, as these factors can influence on the necessity of an orchard before fertilization (Leonel et al., 2020).

There is a paucity of literature that assesses the response of bananas to phosphorus application and such relationship with mineral metabolism, probably it is because the macronutrient is absorbed in smaller amount (Hoffmann et al., 2010). However, there are some evidences that the supplementation may benefit agronomic performance and the quality of banana fruits (Liu et al., 2015; Silva \& Rodrigues, 2013a; Attia, Ahmed, \& El-Sonbaty, 2009).

With regards to the interaction between phosphorus application and crop cycles for plant growth variable of the 'FHIA 18' hybrid, Leonel et al. (2020) found the plant height increases linearly as a function of the phosphorus doses applied in the first cycle. However, phosphorus promoted a quadratic increase in plant height in both second and third cycles, with a maximum rate at 30 and 29 of $\mathrm{P}_{2} \mathrm{O}_{5}\left(\mathrm{~kg} / \mathrm{h}^{-1}\right)$, respectively.

Fertilization was highly influenced by irrigation in banana orchards, especially potassium, contributing to better plant nutrition (Martins, Narita, Suguino, \& Takata, 2011). Pereira et al. (2019) evaluated banana genotypes of 'Prata Anã' between 2015 and 2017 in orchards with irrigated and rainfed systems in Minas Gerais. The authors concluded that fruit production in irrigated system was $60 \%$ higher than rainfed one, confirming the viability of the use of water supplementation for growing bananas. In a study carried out in the city of Vera Cruz, in the mid-west of São Paulo state, Martins, Narita, Suguino and Takata (2020) aimed to evaluate the performance of banana genotypes under micro-sprinkler and rainfed irrigation. According to the authors, the micro-sprinkler irrigation positively interferes in the vegetative and productive characteristics of banana trees of Galil 18 cultivar (Prata subgroup).

\section{THE CULTIVAR DIVERSIFICATION OF THE CAVENDISH SUBGROUP}

The Cavendish subgroup has attained great importance in banana production, since are either destined for export or for domestic consumption (Lima et al., 2012). These bananas have a very distinctive thin, long, curved shaped fruits with a tip or apex in the form of a bottleneck; the ripe fruits are yellow and green with a sweet flavour. The plants may have red sheaths, waxy and green petiole, an olivegreen coloured pseudo-stem with brown and black spots, and a slight cone-shaped cluster (Lima et al., 
2012). One of the main variations of the subgroup is related to the plant's size, which is therefore used to divide them into five categories: very small, small, medium, medium tall, and tall (Shepherd, 1984).

The Cavendish subgroup is formed by a set of cultivars that are highly sensitive to mutations, since clonal sum variations in banana plants occur at a much higher level than other crops, it may happen due to mitotic instability (i.e. mitosis that the end results in cell production with different ploidy). This can also be observed in field at lower frequencies; thus, demonstrating that is not exclusive in tissue culture (Hwang \& Tang, 1996).

Therefore, one can explain the appearance of dozens of cultivars of the AAA genome group (Cavendish subgroup). Although, the cultivars of this subgroup are mutation-sensitive in terms of size, the Cavendish subgroup are widely commercialized. Among the main cultivars of this subgroup, it can be mentioned the following: Nanica, Nanicão, Willians Hybrid, and Grand Naine (Lima et al., 2012).

The Nanica cultivar (AAA) is the most widespread in the world. This cultivar is very small (from 1.5 to 2.0 $\mathrm{m})$, the pseudo-stem presents brown to black patches on an olive green background with a cone-shaped cluster that weighs from 25 to $45 \mathrm{~kg}$; the fruits of the first bunch are arranged in a disorderly manner. The cluster has from 10 to 13 bunches, each bunch has about 16 to 34 fruits, totalling 150-272 bananas. The fruit measures $14-25 \mathrm{~cm}$, weighs from 87 to $260 \mathrm{~g}$, has a rounded apex, medium pedicel, and the ripe fruits are green and yellow. The pulp ranges from creamy white to pale yellow, with a pleasant sweet taste (Cordeiro, 2000).

'Nanicão' (AAA) is a mutation of 'Nanica' that occurred in the State of São Paulo. According to Cordeiro (2000), the size of this cultivar is between $3.00-3.50 \mathrm{~m}$, the pseudo-stem and leaves presents the same colour as Nanica and, a more uncompressed leaf rosette. 'Nanicão' has a cylindrical-shaped cluster (medium to large size) weighing from 25 to $50 \mathrm{~kg}$, the cluster has around 10 to 15 bunches, which has about 16 to 34 fruits, totalling $150-290$ bananas. The 15 to $26 \mathrm{~cm}$ fruits weigh between 90 to $290 \mathrm{~g}$ and are more curved than 'Nanica' ones. These characteristics satisfy the international trade standards. The rachis has a small portion of persistent bracts (smaller than 'Nanica'), covering around $50 \%$ of male flowers. The initial portion of the rachis is devoid of male fruits in the first $10-30 \mathrm{~cm}$.

Grande Naine is another cultivar of Cavendish subgroup (AAA), has high productive capacity, green coloured pseudo-stem with dark spots and medium size, this cultivar is an intermediate between 'Nanica' and 'Nanicão' (Cordeiro, 2000). The clusters are slightly cone-shaped with long, thin, curved shaped fruits that also has rounded tips, short pedicels and the ripe pulp presents a very sweet flavour. 'Grand Naine' is susceptible to yellow and black sigatoka and banana root borer (Cosmopolites sordidus), but resistant to Panama disease (Nomura \& Saes, 2013).

Williams Hybrid is a clone of Nanicão cultivar, is also largely cultivated in Australia and Honduras, where is also known as Giant Cavendish. There is no significant difference towards 'Grand Naine' except for the size that is considered an intermediate between 'Nanicão' and 'Nanica' (Cordeiro, 2000).

With regards to the banana genetic improvement of Cavendish subgroup, there is no possibility to develop tetraploid hybrids yet, because of total female sterility; thus, making reproduction very challenging (Novak, 1992). Therefore, there is a need to use other techniques to obtain new cultivars in this subgroup such as induced mutation or genetic transformation to expand the genetic base (Silva et al., 1999). According to Silva et al. (2004), the selection, collection, and evaluation of Cavendish type bananas in Brazil from the Germplasm Active Bank could offer alternatives for new materials, that is, aiming at using as varieties in production systems.

In consequence field selection and evaluation enabled obtaining cultivars that presented high yield and resistance against pests and diseases, such as 'Nanicão IAC 2001' (AAA), selected by APTA - Agronomic Institute of Campinas (SP), which presents fruits similar to 'Grande Naine', besides being tolerant to yellow and black sigatoka, as well as Panama disease. This cultivar is medium-sized, has cluster weighing from 20 to $45 \mathrm{~kg}$ with up to 11 bunches (Nomura \& Saes, 2013). The fruits are characterized by a smooth and thick peel with light yellow colour and cream-coloured farinaceous pulp. Also, the shelf life and vitamin $\mathrm{C}$ content are significantly longer and higher than 'Nanicão' fruits, respectively (Moreira, 2003). 
Table 2. Main characteristics of traditional cultivars and their potential substitutes belonging to the Cavendish subgroup.

\begin{tabular}{lll}
\hline CULTIVAR & CHARACTERISTICS & REFERENCES \\
\hline & Genotype: AAA; & (Cordeiro, 2000; Jesus et al., 2004; \\
& Susceptible to black and yellow sigatoka; & Aquino 2004; Silva et al., 2004; \\
& Resistant to Panama disease & Cordeiro, 2021) \\
& Size: small; & \\
Nanica & Vegetative cycle: 290 days; & \\
& Cluster weight: 25 to $45 \mathrm{~kg} ;$ & \\
& Number of bunches: 10 a 13; & \\
& Yield: 25 t ha ${ }^{-1} ;$ & \\
& Fruit length: 14 a $25 \mathrm{~cm} ;$ & \\
& Fruit diameter: $3.1 \mathrm{~cm}$. &
\end{tabular}

Genotype: AAA;

(Cordeiro, 2000; Ramos et al., 2009,

Susceptible to black and yellow sigatoka; Lima et al., 2012)

Resistant to Panama disease

Size: medium;

Nanicão

Vegetative cycle: 290 days;

Cluster weight: 25 to $50 \mathrm{~kg}$;

Number of bunches: 10 to 15 ;

Yield: $36.9 \mathrm{t} \mathrm{ha}^{-1}$;

Fruit length: 15 to $26 \mathrm{~cm}$;

Fruit diameter: $3.6 \mathrm{~cm}$.

Genotype: AAA; (Cordeiro, 2000; Nomura \& Saes,

Susceptible to black and yellow sigatoka; 2013; Gonçalves, 2018)

Resistant to Panama disease

Size: medium;

Grand Naine

Vegetative cycle: 300 to 365 days;

Cluster weight: 31 to $40 \mathrm{~kg}$;

Number of bunches: 9 to 11 ;

Yield: $46.9 \mathrm{t} \mathrm{ha}^{-1}$;

Fruit length: 16 to $25 \mathrm{~cm}$;

Fruit diameter: $3.5 \mathrm{~cm}$. 
Susceptible to black and yellow sigatoka; Lima, Santos, Krause, Garbúgio, \&

Resistant to Panama disease;

Santi, 2018)

Size: medium;

Williams Hybrid

Vegetative cycle: 539 days;

Cluster weight: 27 to $34 \mathrm{~kg}$;

Number of bunches: 10;

Yield: $23.45 \mathrm{t} \mathrm{ha}^{-1}$;

Fruit length: 15 a $23 \mathrm{~cm}$;

Fruit diameter: $4.2 \mathrm{~cm}$.

Genotype: AAA;

Resistant to black and yellow sigatoka,

Panama disease;

Size: medium/tall;

Vegetative cycle: 437 days;

Nanicão IAC 2001

Cluster weight: 20 to $45 \mathrm{~kg}$;

Number of bunches: 11;

Yield: $24.32 \mathrm{t} \mathrm{ha}^{-1}$;

Fruit length: $21 \mathrm{~cm}$;

Fruit diameter: $3.4 \mathrm{~cm}$.
(Saes et al., 2005; Moreira 2003;

Bolfarini et al., 2014)

\section{AGRONOMIC PERFORMANCE AND FRUIT QUALITY OF CULTIVARS BELONGING TO CAVENDISH SUBGROUP}

The agronomic characterization normally provides information for the vegetative traits such as pseudostem diameter; plant height; cluster, bunch, and fruit weight; fruit diameter and length; among others. All these traits are relevant to identify and select superior individuals that may be affected by natural or artificial selection; besides the influence caused by the environment. (Amorim et al., 2009). The organoleptic attributes of the fruit (i.e. flavour, shelf life and appearance) is another important characteristic, since banana peel is a factor of great impact on consumers' purchasing decisions (Garruti et al., 2012). Several studies have been carried out regarding the development, production and fruit quality of banana cultivars that are tolerant and resistant to diseases in different edaphoclimatic conditions in recent years in Brazil.

Ferreira and Silva (2002) collected 69 clones of the Cavendish subgroup (49 of the 'Nanicão' type and 20 of the 'Grande Naine' type) of banana producers from the states of São Paulo, Minas Gerais, Bahia and Santa Catarina. The first analysis was therefore made at Embrapa Cassava and Tropical Fruit in Cruz das Almas, state of Bahia. This evaluation considered the agronomic characteristics and fruit quality; thus, the results obtained showed variability in all evaluated traits (Silva et al., 2004). Then, five clones of 'Grand Naine' and four of 'Nanicão' were selected for their superior characters and, then, evaluated in the edaphoclimatic conditions of the northern region of Minas Gerais by Silva et al. (2006). Furthermore, the authors recommended the 'Nanicão IAC Abóbora Verde' and 'Grand Naine Williams' clones, as they present the best agronomic performance with regards to the evaluated characters, according to the experiment conditions.

In a study conducted by Lima et al. (2018) on the cultivars' agronomic performance, the researches selected five cultivars of the Cavendish subgroup, three of the Prata group, three of the Maçã group and one of the Terra group over two productive cycles in Tangará da Serra, state of Mato Grosso. The authors 
found higher productive potential on two cultivars of the Cavendish subgroup (Epagri and Willians), due to the better adaptability regarding to the region's edaphoclimatic conditions.

In the edaphoclimatic conditions of the Palmital, state of São Paulo, Camolesi, Neves, Martins and Suguino, (2012) evaluated the agronomic behaviour of some cultivars of Cavendish subgroup (Nanicão IAC 2001, Nanicão Jangada and Grand Naine). The authors reported that these cultivars showed better vegetative behaviour and productive performance, specially 'Nanicão Jangada' that presented the best performance for almost all the evaluated production traits; thus, being highly indicated for this region.

Bolfarini et al. (2014) also evaluated Nanição IAC 2001 and Grand Naine of the Cavendish subgroup in São Manuel, state of São Paulo. The authors also observed that these cultivars stood out from others in terms of production variables. Nomura et al. (2017) reported that 'Nanição IAC 2001' and 'Grand Naine' showed a great response to nitrogen and potassium fertilizations in Vale do Ribeira, state of São Paulo. The authors applied a dose of $150 \%$ of the recommended fertilization to reach maximum yield, but 'FHIA 17' showed low response.

According to Silva et al. (1999), the cultivars of the Cavendish subgroup obtain better productive performance in relation to the other subgroups, as this cultivar group presents good adaptability and stability to most edaphoclimatic conditions. In addition to producing the largest clusters among edible banana cultivars (Nomura et al., 2017), the cultivars of the Cavendish subgroup are quite demanding in terms of soil fertility, water availability and cultural practices (Cordeiro, 2000).

\section{FINAL COMMENTS}

Many banana genotypes have been developed and evaluated in several researches, which have shown good attributes of agronomic performance and fruit quality. However, studies that assess the sensorial acceptance of these products are needed as much as studies that reach all producers and consumers to share all the findings related to the production system. Therefore, the favourable aspects of each genotype must be emphasized, highlighting the characteristics that favour all production chain, including their sustainability. Thus, attracting the attention not only of banana growers, who wish to increase their production, but also of consumers who seeks for alternative products with food safety and quality assurance, as well as environmentally friendly.

\section{REFERENCES}

Alves, E. J. A. (1999). Cultura da banana: aspectos técnicos, socioeconômicos e agroindustriais (2nd ed.). Brasília, DF: Embrapa.

Amorim, E. P., \& Santos-Serejo, J. A. (2011). BRS Platina: cultivar de bananeira tipo prata resistente ao mal do panamá. Cruz das Almas, BA: Embrapa Mandioca e Fruticultura Tropical.

Amorim, E. P., Lessa, L. S., Ledo, C. A. S., Amorim, V. B. O., Reis, R. V., Santos-Serejo, J. A., \& Silva, S. O. E. (2009). Caracterização agronômica e molecular de genótipos diplóides melhorados de bananeira. Revista Brasileira de Fruticultura, 31(1), 154-161. https://doi.org/10.1590/s0100-29452009000100022

Attia, M., Ahmed, M., \& El-Sonbaty, M. (2009). Use of biotechnologies to increase growth, productivity and fruit quality of Maghrabi banana under different rates of phosphorus. World Journal of Agricultural Sciences, 5(2), 211-220.

Aular, J., \& Natale, W. (2013). Nutrição mineral e qualidade do fruto de algumas frutíferas tropicais: Goiabeira, mangueira,bananeira e mamoeiro. Revista Brasileira de Fruticultura, 35(4), 1214-1231. https://doi.org/10.1590/S0100-29452013000400033

Azevedo, V. F., Donato, S. L. R., Arantes A. M., Maia V. M., \& Silva S. O. (2010). Avaliação de bananeiras tipo Prata, de porte alto, no Semiárido. Ciência e Agrotecnologia, 34(6), 1372-1380. https://doi.org/10.1590/S1413-70542010000600003

Bolfarini, A. C. B., Javara, S. F., Leonel, S. \& Leonel, M. (2014). Crescimento, ciclo fenológico e produção de cinco cultivares de bananeira em condições subtropicais. Revista Raízes e Amidos Tropicais, 10(1), 7489. 
Borges, A. L., \& Souza, L. S. (2004). Exigências edafoclimáticas - o cultivo da bananeira. Cruz das Almas, BA: Embrapa Mandioca e Fruticultura Tropical.

Camolesi, M. R., Neves, C. S. V. J., Martins, A. N., \& Suguino, E. (2012). Desempenho de cultivares de bananeiras na região do Médio Paranapanema, São Paulo. Semina: Ciencias Agrarias, 33(SUPPL.1), 2931-2938. https://doi.org/10.5433/1679-0359.2012v33Supl1p2931

Cayón, G., Valencia, J., Morales, H., \& Domínguez, A. (2004). Desarrollo y producción del plátano DominicoHartón (Musa AAB Simmonds) en diferentes densidades y arreglos de siembra. Agronomia Colombiana, 22(1), 18-22.

Cordeiro, Z. J. M. (2000). Banana - produção: aspectos técnicos. Brasília, DF: Embrapa - SPI.

Cruz-Junior, F. S., Gueco, L. S., Damasco, O. P., Huelgas, V. C., Banasihan, I. G., Lladones, R. V., Bergh, I., \& Molina, A. B. (2007). Catalogue of introduced and local banana cultivars in the Philippines: Results of a demonstration trial by the Institute of Plant Breeding. Laguna, Philippines: Institute of Plant Breeding, University of the Philippines Los Baños.

Dantas, J. L. L. (1999). Citogenética e melhoramento genético. In E. J. Alves (Ed.), A cultura da banana: aspectos técnicos, socioeconômicos e agroindustriais (2nd ed.). Brasília, DF: Embrapa.

Destro, T. M., Souza-Junior, H., Lima, T. G., Miranda, L. A., \& Ferreira, M. P. (2020). Potential use of green banana biomass in the preparation of chocolate cake and salty pie. Agronomy Science and Biotechnology, 6, 1-11. https://doi.org/10.33158/ASB.r129.v6.2020

Deltour, P., França, S. C., Pereira, O. L., Cardoso, I., Neve, S., Debode, J., \& Höfte, M. (2017). Disease suppressiveness to Fusarium wilt of banana in an agroforestry system: Influence of soil characteristics and plant community. Agriculture, Ecosystems and Environment, 239, 173-181. https://doi.org/10.1016/j.agee.2017.01.018

Donato, S. L. R., Arantes, A. M., Silva, S. O., \& Cordeiro, Z. J. M. (2009). Comportamento fitotécnico da bananeira "Prata-Anã" e de seus híbridos. Pesquisa Agropecuária Brasileira, 44(12), 1608-1615. https://doi.org/10.1590/s0100-204×2009001200007

EMBRAPA - Empresa Brasileira de Pesquisa Agropecuária. (2012). BRS Platina - Uma nova banana Prata. Boletim Informativo. Cruz das Almas, BA: Embrapa Mandioca e Fruticultura Tropical.

EMBRAPA - Empresa Brasileira de Pesquisa Agropecuária. (2020a). Banana BRS Japira. Brasília, DF: Embrapa.

EMBRAPA - Empresa Brasileira de Pesquisa Agropecuária. (2020b). Banana BRS Vitória. Brasília, DF: Embrapa.

Fancelli, M. (2003). Cultivo da bananeira para o Estado do Amazonas: cultivares. Cruz das Almas, BA: Embrapa - CNPTIA.

FAO - Food and Agriculture Organization of the United Nations. (2020). Fa. FAOSTAT. Retrieved from http://www.fao.org/faostat/en/

Ferreira, F. R., \& Silva, S. O. (2002). Collecting banana germplasm from the AAA genomic group/Cavendish subgroup. Cropp Breeding and Applied Biotechnology, 2(3), 485-488. https://doi.org/10.12702/19847033.v02n03a23

Garruti, D. S., Matias, M. L., Facundo, H. V. V., Silva, E. O., Costa, J. N., \& Silva, M. A. A. P. (2012). Aceitação de cultivares de bananas resistentes à Sigatoka Negra junto ao consumidor da região Nordeste do Brasil. Ciência Rural, 42(5), 948-954. https://doi.org/10.1590/s0103-84782012000500030

Godoy, R. C. B., Waszczynskj, N., Satana, F. A., Silva, S. O., Oliveira, L. A., \& Santos, G. G. (2016). Physicochemical characterization of banana varieties resistant to black leaf streak disease for industrial purposes Guilherme Godoy dos Santos V Banana Germplasm Bank at Embrapa 's Cassava. Ciência Rural, 46(9), 1514-1520. 
Hwang, S. C., \& Tang, C. Y. (1996). Somaclonal variation and its use for Improving Cavendish (AAA desert) bananas in Taiwan. In D. Frison, E. A., Horry, J. P., \& Waele (Ed.), New Frontiers IN Resistance for Nematode Fusarium and Sigatoka (pp. 173-181). Kuala Lumpur, Malaysia: INIBAP.

IBGE - Instituto Brasileiro de Geografia e Estatística. (2020). Banco de dados agregados - Sidra - produção agrícola municipal. Rio de Janeiro, RJ: IBGE. Retrieved from https://www.ibge.gov.br/

Leonel, S., Bolfarini, A. C. B., Souza, J. M. A., Leonel, M., Ferreira, R. B., Putti, F. F., \& Tecchio, M. A. (2020). Agronomic performance of Banana 'FHIA 18' in response to phosphate fertilization. Agronomy Journal, 112(3), 2033-2046. https://doi.org/10.1002/agj2.20166

Lichtemberg, L. A., \& Lichtemberg, P. S. F. (2011). Avanços na Bananicultura Brasileira. Revista Brasileira de Fruticultura, 33(SPEC. ISSUE 1), 029-036. https://doi.org/10.1590/s0100-29452011000500005

Lima, E. C. S., Santos, P. R. J., Krause, W., Garbúgio, E., \& Santi, A. (2018). Desempenho agronômico de cultivares de bananas em dois ciclos produtivos em Tangará da Serra-MT. Revista Engenharia na Agricultura, 26(6), 497-506. https://doi.org/10.13083/reveng.v26i6.812

Lima, M. B., Silva, S. O., \& Ferreira, C. F. (2012). Banana: o produtor pergunta, a Embrapa responde. Brasília, DF: Embrapa.

Liu, Y., Jing, T., Tang, F., Zang, X., Zheng, W., Cao, H., Ju, J., Wang, B., \& Li, C. (2015). Studies on the fertilization effect and optimal fertilizing amount of Brazil banana based on "3414" field trials. Agricultural Science \& Technology, 16(9), 1950-1954.

Magalhães, D. B., Donato, S. L. R., Santos, M. R., Brito, C. F. B., Fonseca, V. A., \& Souza, B. S. (2020). Yield of 'Prata-Anã' banana plants under water deficit and high plant density. Revista Brasileira de Fruticultura, 42(5), 0-3. https://doi.org/10.1590/0100-29452020046

Martins, A. N., Teixeira, L. A. J., Suguino, E., Hashimoto, J. M.,\& Narita, N. (2011). Irrigação E Adubação Potássica Via Irrigation and Potassium Fertilization By Fertigation. Revista Brasileira de Fruticultura, 33(1), 743-751.

Martins, A. N., Narita, N., Suguino, E., \& Takata, W. H. S. (2020). Desempenho de genótipos de bananeiras em cultivos irrigado e sequeiro, na região Centro Oeste Paulista. Colloquium Agrariae, 16(1), 11-18. https://doi.org/10.5747/ca.2020.v16.n1.a343

Matsuura, F. C. A. U., Costa, J. I. P., \& Folegatti, M. I. S. (2004). Marketing de banana: preferências do consumidor quanto aos atributos de qualidade dos frutos. Revista Brasileira de Fruticultura, 26(1), 4852. https://doi.org/10.1590/s0100-29452004000100014

Moreira, R. S. (2003). Nossa nanica está garantida. São Paulo, SP: Revista Rural.

Nogueira, S. R., Andrade-Neto, R. C., Capistrano, M. C., Lessa, L. S., Alécio, M. R., \& Santos, V. B. (2018). Performance of banana genotypes in Rio Branco, Acre, Brazil. Revista Brasileira de Ciências Agrárias Brazilian Journal of Agricultural Sciences, 13(4), 1-9. https://doi.org/10.5039/agraria.v13i4a5576

Nomura, E. S., \& Saes, L. A. (2013). Avaliação de cultivares e híbridos de bananeira. In L. O. S. Nogueira, E. M. C., Almeida, I. M. G., Ferrari, J. T., \& Beriam (Ed.), Bananicultura: manejo fitossanitário e aspectos econômicos e sociais da cultura (p. 243). São Paulo, SP: Instituto Biológico.

Nomura, E. S., Moraes, W. S., Damatto Junior, E. R., Fuzitani, E. J., Saes, L. A., Amorim, E. P., \& Silva, S. O. (2013). Evaluation of banana genotypes over two crop cycles under subtropical conditions in the ribeira valley São Paulo Brazil. Acta Horticulturae, 986, 61-70. https://doi.org/10.17660/ActaHortic.2013.986.4

Nomura, Edson Shigueaki, Cuquel, F. L., Damatto Junior, E. R., Fuzitani, E. J., \& Borges, A. L. (2017). Adubação nitrogenada e potássica nas bananeiras 'grande Naine', 'FHIA 17' e 'nanicão IAC 2001' cultivadas no Vale do Ribeira, estado de São Paulo, Brasil. Acta Scientiarum - Agronomy, 39(4), 505-513. https://doi.org/10.4025/actasciagron.v39i4.32919

Novak, F. J. (1992). Musa (banana and plantatins). In R. E. Hammerschlag, F. A., \& Litz (Ed.), Biotechnology of perennial fruits crops (pp. 449-476). Wellingford: CAB International. 
Oliveira, C. G., Donato, S. L. R., Mizobutsi, G. P., Silva, J. M., \& Mizobutsi, É. H. (2013). Características póscolheita de bananas "Prata-Anã" e "BRS Platina" armazenadas sob refrigeração. Revista Brasileira de Fruticultura, 35(3), 891-897. https://doi.org/10.1590/s0100-29452013000300028

Pereira, J. C. R., Gasparoto, L., \& Pereira, M. C. N. (2005a). BRS Japira: cultivar de bananeira resistente à sigatoka-negra e à antracnose para o estado do Amazonas. Manaus, AM: Embrapa Amazônia Ocidental.

Pereira, J. C. R., Gasparoto, L., \& Pereira, M. C. N. (2005b). BRS Vitória: nova cultivar de bananeira do subgrupo prata para o agronegócio no estado do Amazonas. Manaus, AM: Embrapa Amazônia Ocidental.

Pereira, L. V., Andrade, J. C., Alvarenga, Â. A., Norberto, P. M., Leite, G. D. F., \& Oliveira, S. (2019). Productive behavior of cultivars and banana genotype originating from ' Prata Anã ', Irrigated and non irrigated in the State of Minas Gerais, Brazil. International Journal of Environmental \& Agriculture Research, 5(1), 1-7.

Perez, F. P. Z., Simão, S., \& Manica, I. (1973). A influência da época de seleção do rebento sobre o desenvolvimento das plantas matrizes em bananeira Musa cavendish II Lamb. Cv Nanicão. Anais da Escola Superior de Agricultura Luiz de Queiroz, 30(0), 335-351. https://doi.org/10.1590/s007112761973000100026

Santos, S. C., Carneiro, L. C., Neto, A. N. D. S., Paniago, E., De Freitas, H. G., \& Peixoto, C. N. (2006). Caracterização morfológica e avaliação de cultivares de bananeira resistentes a Sigatoka Negra (Mycosphaerella fijiensis Morelet) no sudoeste goiano. Revista Brasileira de Fruticultura, 28(3), 449453. https://doi.org/10.1590/S0100-29452006000300024

Shepherd, K. (1984). Evolução e classificação das bananeiras. Cruz das Almas, BA: Embrapa Mandioca e Fruticultura Tropical.

Silva, J. T. A., \& Borges, A. L. (2008). Solo, nutrição mineral e adubação da bananeira. Informe Agropecuário, $29,33-34$.

Silva, S. O., Alves, E. J., Lima, M. B., \& Silveira, J. R. S. (2002). Bananeira. In C. H. Bruckner (Ed.), Melhoramento de Fruteiras Tropicais (pp. 101-157). Viçosa, MG: Editora UFV.

Silva, S. O., Gasparotto, L., Matos, A. P., Cordeiro, Z. J. M., Ferreira, C. F., Ramos, M. M., \& Jesus, O. N. (2003). Programa de melhoramento de bananeira no Brasil - resultados recentes. Cruz das Almas, BA: Embrapa Mandioca e Fruticultura Tropical.

Silva, S. O., Pires, T. E., Pestana, R. K. N., Alves, J. S., \& Silveira, D. C. (2006). Avaliação de clones banana Cavendish. Ciencia e Agrotecnologia, 30(5), 832-837.

Silva, S. O., Shepherd, K., Alves, E. J., \& Dantas, J. L. L. (1999). Cultivares de banana. In E. J. Alves (Ed.), A cultura da banana: aspectos técnicos, socioeco-nômicos e agroindustriais (p. 105). Brasília, DF: Embrapa - SPI.

Silva, S. O. E., Santos-Serejo, J. A., \& Cordeiro, Z. J. M. (2004). Variedades. In L. S. Borges, A. L., \& Souza (Ed.), O cultivo da bananeira (pp. 45-58). Cruz das Almas, BA: Embrapa Mandioca e Fruticultura Tropical.

Silva, J. T. A., \& Rodrigues, M. G. V. (2013a). Produção da bananeira "Prata Anã" em função da aplicação de adubo fosfatado, em quatro ciclos. Pesquisa Agropecuaria Brasileira, 48(6), 613-618. https://doi.org/10.1590/S0100-204X2013000600006

Silva, M. J. R., Jesus, P. R. R., Anjos, J. M. C., Machado, M., \& Ribeiro, V. G. (2016). Caracterização agronômica e pós-colheita das bananeiras "Maravilha" e "Preciosa" no submédio do Vale São Francisco1. Revista Ceres, 63(1), 46-53. https://doi.org/10.1590/0034-737X201663010007

Silva, S. de O. E., Amorim, E. P., Santos-Serejo, J. A. dos, Ferreira, C. F., \& Rodriguez, M. A. D. (2013b). Melhoramento genético da bananeira: Estratégias e tecnologias disponíveis. Revista Brasileira de Fruticultura, 35(3), 919-931. https://doi.org/10.1590/\$0100-29452013000300032 
Smith, M. K., Langdon, P. W., Pegg, K. G., \& Daniells, J. W. (2014). Growth, yield and Fusarium wilt resistance of six FHIA tetraploid bananas (Musa spp.) grown in the Australian subtropics. Scientia Horticulturae, 170, 176-181. https://doi.org/10.1016/j.scienta.2014.02.029

Tenkouano, R., Ortiz, R., \& Baiyeri, K. P. (2002). Phenotypic and genetic correlations in Musa populations in Nigeria. African Crop Science Journal, 10(2), 121-132. https://doi.org/10.4314/acsj.v10i2.27544

Weber, O. B., Santos Garruti, D., Norões, N. P., \& Silva, S. O. (2017). Performance of banana genotypes with resistance to black leaf streak disease in Northeastern Brazil. Pesquisa Agropecuaria Brasileira, 52(3), 161-169. https://doi.org/10.1590/S0100-204X2017000300003

Received: February 8, 2021.

Accepted: March 16, 2021.

Published: May 10, 2021.

English by: Guilherme Augusto Rago Ferraz. 